ORIGINAL SCIENTIFIC PAPER

\title{
Effect of Parkia biglobosa husk extracts and honey blend on the chemical, sensory and bacterial attributes of traditional West African soft cheese
}

\author{
Abdulhameed Abiodun Badmos ${ }^{* 1}$, Kazeem Dauda Adeyemi ${ }^{1}$, Samson Adeoye Oyeyinka ${ }^{2}$, \\ Risikat Nike Ahmed ${ }^{3}$, Fatimoh Titilope Akande', Abdulkareem Olusegun Lawal ${ }^{4}$ \\ 1 University of Ilorin, Department of Animal Production, Ilorin, Nigeria \\ 2 University of Ilorin, Department of Home Economics and Food Science, Ilorin, Nigeria \\ 3 University of Ilorin, Department of Microbiology, Ilorin, Nigeria \\ 4 ITAD Ltd, Hove, United Kingdom \\ *Corresponding Author:+2348065550095, badmos111@yahoo.com
}

Abstract

This study examined the effect of Parkia biglobosa (Locust bean) husk extract and honey blend on the chemical, sensory and bacterial qualities of traditional West African soft cheese. In this study, soft cheese was treated with blends of honey and ethanol extract of P. biglobosa husk at varied levels of 0, 1, 2, 3 or 4\% (being percentages of the milk used) for both of the components immediately after coagulation. Seven (7) treatments were studied in a completely randomized design and assessment of the proximate composition and sensory attributes of the cheese was done. The Total Bacterial Count (TBC) was also monitored throughout a five days period. The result revealed that the control cheese was highest in moisture, and ash, but lower in cheese fat content. General acceptability was highest for the cheese curds fortified at 1:3, 2:2 and 3:1 $\%$ Honey/P. biglobosa. The 3/1: Honey/P. biglobosa treated cheese showed the highest inhibition rate against bacterial growth. The treatments fortified with 1:3, 2:2 and 3:1\% Honey/P. biglobosa also had the lowest TBC for the days of microbial assay. Seratia odonrifera and Seratia liqueficiens were prominently identified at days 2 and 4 of storage. The study recommend the use of 1:3 , 2:2 and 3/1 \% Honey/ P. biglobosa cheese curd fortification as an improvement of the nutritional, sensory and bacterial attributes of West African soft cheese.

Keywords: Cheese quality, Honey, Parkia biglobosa, bacterial assay, shelf life

\section{Introduction}

Cheese is one of the major products obtained from processing of milk of cows, goats, sheep, buffalos, camels and yaks (Akinloye and Adewumi, 2014). It is a highly nutritious food product made by the coagulation of milk protein known as casein. Cheese is regarded as an important source of protein as it may replace meat or fish or be used in combination with these animal proteins in various food recipes (Aworh and Egounlety, 1985). Different types of cheese exist, depending on the location and the processing methods. In most West African countries, including Nigeria, milk casein is coagulated using extracts of sodom apple leaf (Calotropis procera) to produce West African Soft Cheese (Akinloye and Adewumi, 2014). Sodom apple leaf is reported to contain calotropin which has the ability to solidify/coagulate milk (Aworh and Muller, 1987). Enzyme in the juice demonstrated typical reactions of milk-clotting proteinase of plant origin (Ogundiwin and Oke, 1983).

Nutritionally, cheese represent an excellent source of protein, fat and minerals such as calcium, iron and phosphorus, vitamins and essential amino acids, making it an important food in the diet of all age groups (Raheem, 2006). This richness in nutrients however, makes cheese important substrate for mi- croorganisms as well. The nutritional importance of cheese has been undermined in West Africa by poor refrigerating facilities and poor preservative media. Soft cheese provides an excellent medium for the growth of many kinds of micro-organisms, possibly due to the high moisture content of the cheese and a favourable $\mathrm{pH}$ for microbial growth (Adesokan et al., 2008). This microbial growth limits the shelf life of soft cheese. West African Soft Cheese (Wara) has an average shelf life of 2-3 days when stored in whey at room temperature of approximately $28^{\circ} \mathrm{C}$ or $4-5$ days when placed in cool water of approximately $15^{\circ} \mathrm{C}$ ) (Adegoke et al., 1992; Belewu et al., 2005).

Various methods used for cheese preservation are well documented in the literature (Aworh and Egounlety, 1985; Joseph and Akinyosoye, 1997; Badmos and Abdulsalam, 2012; Badmos et al., 2017). Synthetic preservatives are expensive and have been reported to have carcinogenic side effects (Alvarez-Suarez et al., 2012). Hence, researchers are seeking for natural alternatives that are safe and effective for cheese preservation. Earlier work studied the effects of ginger extract, garlic extract, lemon grass extract, thyme, and alligator pepper on cheese preservation (Belewu et al., 2013; Badmos et al., 2017). Badmos et al. (2017) studied the effect of different concentrations of aqueous and ether extracts of the Aframomum melegueta on the bacterial count, proximate composition and 
sensory evaluation of West African Soft Cheese. According to their report, $3 \%$ ether extract had the highest inhibitory effect on bacterial growth in the cheese samples.

Other promising natural alternatives that can be explored in cheese preservation are honey and locust bean (Parkia biglobosa) extracts due to their antimicrobial properties. For instance, Fawole and Abioye (2002) reported that Parkia husk extract has fungicidal properties. Other authors found that the husk contains tannins, polyphenols, flavonoids, alkaloids, saponins, anthraquinones and glycosides (Twumasi and Awudza, 2013). Recently, there is evidence that the enzyme system in honey such as glucose oxidase may slowly release hydrogen peroxide at a level which is antibacterial but not tissue-damaging (Aurongzeb and Azim, 2011). According to these authors, the antimicrobial effect of honey may be associated with the presence of alkaloids, flavonoids/ isoflavones, glycosides, phenolics and peptides. Due to the low shelf life of cheese when not refrigerated, as is most West African countries, there may be need to further explore potentially cheap alternatives to chemical preservatives that has been previously reported for cheese preservation. The antimicrobial properties of honey have great potential for application in medicine as well as in food industry. To the best of authors' knowledge, there are no reports on the use of Parkia husk ether extract and honey on the quality of West African soft cheese. Hence, the aim of this study is to determine the effect of the blend of Parkia husk ether extract and honey on the proximate composition, sensory properties and microbial quality of West African soft cheese.

\section{Materials and Methods}

Preparation of honey solution and ether extract of Parkia biglobosa

Honey was obtained from the University of Ilorin Apiary and diluted (at $10 \%$ ) with distilled water (Badmos et al., 2017).

Parkia (P. biglobosa) husks were collected and washed thoroughly with distilled water. The husks were oven dried at $45{ }^{\circ} \mathrm{C}$ for 3 days. The dried husks were well grinded into fine powder using electrical grinder. The powdered husks (50 g) were percolated with $250 \mathrm{~mL}$ of petroleum ether at room temperature for 24 hours and filtered. The extracts obtained were concentrated at $50{ }^{\circ} \mathrm{C}$ to give ether extracts of the husks (Afolabi and Adegoke, 2011; Kalita et al., 2012).

\section{Sodom apple juice extraction}

Some quantities of sodom apple leaves were collected, rinsed and air-dried. Portions were weighed to $10 \mathrm{~g}$, crushed with a sterilized enamel mortar and pestle, after which 20 $\mathrm{mL}$ of distilled water was added and the resulting mash was squeezed out with a muslin cloth (Badmos and Joseph, 2012).

\section{Cheese making}

Whole milk (1000 mL) was poured into seven separate heating vessels each and, immersed in a heated water bath. The milk in the vessels were heated to approximately $50{ }^{\circ} \mathrm{C}$ for about 30-40 minutes while $30 \mathrm{ml}$ of the leaf extracts of $\mathrm{Ca}$ lotropis procera (Sodom apple) were then added to the warm milk in each vessel (30ml of juice equals $3 \%$ of milk used).
Gentle heating at about $40{ }^{\circ} \mathrm{C}$ continued until coagulation started about 15-20 minutes later.

Honey and ether extract of $P$. biglobosa husk was added at different concentrations (Table 1), as soon as curd formation began. The curd was heated in whey for a further 20 minutes to enable whey expulsion and inactivate the plant enzyme. The cheese curd was then removed and put in separate raffia baskets to enable drainage of whey and to give it desired shape and size.

\section{Analyses}

\section{Proximate analysis}

Moisture, fat, protein and ash contents were determined using AOAC (2000) methods. Protein content was determined by the Kjeldahl method $(6.25 \times \mathrm{N})$ and total carbohydrate was calculated by difference, i.e. Carbohydrate $=100$-(moisture + fat + fibre + ash + protein).

\section{Sensory evaluation}

A thirty (30) member trained panelists (staff and students) examined the samples independently. Evaluation was based on colour, texture, aroma, taste and overall acceptability. Score was based on hedonic scale of 1-9 (1=like extremely and $9=$ dislike extremely). The selected panel members were those accustomed to eating cheese. Prior to the sensory analysis, they were screened with respect to their interest and ability to differentiate food sensory properties. The samples were evaluated for colour, taste, aroma, texture and overall acceptability.

\section{Total bacterial count and assay}

The total bacterial counts of the cheese samples were determined as previously reported (Badmos and Ajiboye, 2012). Cheese samples were aseptically taken at $0 \mathrm{~h}$ (day 0 ), $48 \mathrm{~h}$ (day 2) and $96 \mathrm{~h}$ (day 4) after production. Serial dilutions of individual cheese samples was carried out (1g cheese per $9 \mathrm{ml}$ distilled water) then plated on nutrient agar plates. The plates were incubated at $37^{\circ} \mathrm{C}$ for 48 hours. The total number of viable bacteria cell colonies were counted for the three replications and the values expressed as colony forming units per gram (Log cfu g-1).

\section{Statistical analysis}

Experiments were replicated five times and the collected data were subjected to the analysis of variance using a completely randomized design. The difference between the means was separated using Duncan Multiple range test.

\section{Results and discussion}

\section{Cheese Composition}

Moisture (approx. 57-60 \%) was the major component of the cheese samples (Table 2). Honey addition appear to slightly increase the moisture content of the cheese samples. The slight increase in moisture might not lead to microbial growth and spoilage since the high content of sugars including sucro- 
se, fructose and glucose in honey makes water unavailable to microbes during storage. Previous authors reported similar moisture content (approx. 60\%) for cheese produced from cow milk (Akinloye and Adewumi, 2014). However, earlier studies reported much lower moisture contents for cheese coagulated with calf rennet (approx. 45\%) and vegetable rennet (approx. 50\%) (Aworh and Muller, 1987). Variation in reported moisture content values for West African cheese samples may be due to different processing methods adopted in the respective studies. Furthermore, it is possible that the initial moisture content of the milk samples may also contribute to the variation in moisture of the cheese samples. Other factors that may account for variation in the moisture content of the cheese samples could be due the concentration of enzymes in the Sodom apple leave extract, which were obtained at different times, of different species, from different locations and whose extracts were obtained through different methods and environment (Akinloye and Adewumi, 2014).

Other components of the treated cheese samples such as ash (1.62-4.64\%), fat (12.13-15.84\%), carbohydrate (9.11$14.63 \%$ ) and protein (approx. $13 \%$ ) contents were generally low. Fat content and fatty composition of cheeses are important components that can significantly affect the flavour of cheese samples (Cuffia et al., 2015).

The protein contents of the cheese samples were very similar and not substantially affected by the addition of honey or P. biglobosa husk. Earlier studies reported similar protein content (12.47-13.75\%) for cheese made from cow milk coagulated with Calotropis procera leaves (Balogun et al., 2016; Badmos et al., 2017). However, much higher protein contents have been previously reported for cheese made from sheep (approx. 23\%) or Carmel's (approx. 17\%) milk (Derar and El Zubeir, 2014). These variations in the protein contents suggest that cheese protein may vary with the type of milk, the composition as well as the processing conditions. This seems plausible since higher protein contents (19.21-23.61\%) were reported for cheese samples treated with Moringa oleifera leaf extracts (Badmos and Ajiboye, 2012), which could be due to the high protein in Moringa oleifera leaf (Moyo et al., 2011).

\section{Sensory evaluation}

With the exception of the rating for colour, the control cheese had low ratings for taste, aroma, texture and general acceptability when compared to the treated samples (Table 3). There seems to be an improvement in the sensory properties of the cheese samples with honey and P. biglobosa husk. The addition of honey or P. biglobosa husk alone both had similar scores for taste, aroma and general acceptability. The sensory panelists observed that treatment 6 (ratio of honey and Parkia husk (H:P) 0:4\% had the highest colour rating, and that treatments 2, 3 and 4 were high in taste and aroma (1:3, 2:2\% and $3: 1 \% \mathrm{H}: \mathrm{P}$ husk). The appearance of the control cheese is more acceptable apparently because in the other treatments some pigments were added to cheese from the blend of P. biglobosa husk ether extract and honey, which apparently affected the appearance. Furthermore, the general acceptability was lowest for the treatment 1 (control) and 7 (4:4 \% H:P husk). The blend of honey and P. biglobosa husk ether extract in treatment 2, 3, 4, 5 and 6 apparently gave a peculiar cheese flavour that was mildly astringent and appealing. The blending components was much in quantity, and this changed the original taste of cheese (which the panelists are familiar with) appreciably, and was perhaps the reason for the low acceptability of treatment 7 (4:4 $\% \mathrm{H}: \mathrm{P}$ husk). The value of blending natural preservatives was earlier reported by an earlier study where the blending of eucalyptus oil and lemon grass oil improved the lavor and general acceptability of West African soft cheese (Belewu et al., 2012).

\section{Bacterial assay}

The control cheese had the highest bacterial population compared with the treated samples throughout the storage period (Table 4). Bacteria population of cheese samples significantly $(\mathrm{p}<0.05)$ reduced with the addition of honey or extract of P. biglobosa and their combinations (Table 4). The reduction in bacteria load of the treated cheese samples during the storage period of microbial examination suggest that honey and extract of $P$. biglobosa are potent antibacterial at all the blending proportions examined. There are evidences in the literature on the antimicrobial potentials of P. biglobosa husk (Twumasi and Awudza, 2013) and honey (Aurongzeb and Azim, 2011). Earlier reports on the husk of $P$. biglobosa found that the extract contain many antimicrobials (Ajaiyeoba, 2002; Twumasi and Awudza, 2013). Furthermore the glucose oxidase of honey has also been reported to metabolise the simple sugars to produce hydrogen peroxide which may compliment the antimicrobial activity of P. biglobosa husk (Aurongzeb and Azim, 2011). Although the exact mechanism for the antimicrobial effect of honey and P. biglobosa husk remains unclear, it is possible that the presence of phytochemicals such as tannins, polyphenols, flavonoids, alkaloids, saponins, anthraquinones and glycosides in these materials are responsible for their antimicrobial properties. Cheese samples treated with honey and extract of $P$. biglobosa at ratios 1:3\% respectively had the lowest bacteria counts (5.52 Log cfu/g) among the treated samples (Table 4). The two ingredients apparently have antibacterial properties either singly or in combination, but the combination treatment appears to work synergistically to further enhance the reduction of the bacteria during storage. Simple sugars in the honey has been long recognized as an antimicrobial agent with the ability to reduce the water activity of foods due to the humectant nature of the simple sugars such as glucose and fructose. Thus, it is possible that the honey in the cheese samples makes water unavailable for the microbes during storage.

Acinetobacter baumannii, Strenotrophomonas maltophilia Seratia odonrifera and Seratia liqueficiens were identified in the cheese samples (Table 5). The population of Serratia species and Acinetobacter baumannii appears antagonistic as rapid growth of one inhibits the other. For instance, while Serratia species were found on the day of production, Acinetobacter baumannii was not present. However, at day 2 of storage, Acinetobacter baumannii was present, but none of the Serratia species were found (Table 5). Serratia species are reportedly opportunistic, gram negative bacteria that is widespread in the environment (Donnenberg, 2010). These oragnisms are not a common component of the human fecal flora, thus, their presence in the cheese samples possibly resulted from contamination from the environment. Microbiological quality of West African soft cheese depends on several factors including quality of the raw milk, processing conditions and post-process contamination (Aworh and Egounlety, 1985). 


\section{Conclusions}

West African soft cheese may be preserved using honey alone or in combination with ether extract of $P$. biglobosa husk. All the treated cheese samples had better sensory properties compared with the control cheese. Cheese treated with honey and extract of $P$. biglobosa at ratios 1:3, 2:2 and 3:1 \% respectively had comparable protein content to the control cheese and lowest bacteria count during storage. Freshly coagulated cheese curds may be treated with the blend of P. biglobosa and honey to improve the nutritional and sensory properties and may potentially be used to extend the shelf life of West African soft cheese.

\section{References}

Adegoke, G., Nse, E., Akanni, A. (1992) Effects of heat, processing time and $\mathrm{pH}$ on the microflora, aflatoxin content and storability of "wara", a soft, white cheese. Molecular $\mathrm{Nu}$ trition \& Food Research, 36 259-264.

Adesokan, I., Odetoyinbo, B., Olubamiwa, A. (2008) Biopreservative activity of lactic acid bacteria on suya produced from poultry meat. African Journal of Biotechnology, 7 37993803.

Afolabi, M., Adegoke, G. (2011) Phytochemical characterization of the extracts of Aframomum danielli flower, leaf, stem and root. African Journal of Agricultural Research, $697-$ 101.

Ajaiyeoba, E. O. (2002) Phytochemical and antibacterial properties of Parkia biglobosa and Parkia bicolor leaf extracts. African Journal of Biomedical Research, 5 125-129.

Akinloye, A., Adewumi, O. (2014) Effects of local coagulants on the yield of cheese using cow and sheep milk. International Journal of Development and Sustainability 3 150-161.

Alvarez-Suarez, J. M., Giampieri, F., González-Paramás, A. M., Damiani, E., Astolfi, P., Martinez-Sanchez, G., Bompadre, S., Quiles, J. L., Santos-Buelga, C., Battino, M. (2012) Phenolics from monofloral honeys protect human erythrocyte membranes against oxidative damage. Food and Chemical Toxicology, 50 1508-1516.

AOAC (2000) Official methods of analysis (17th ed.) Washington DC: Association of official Analytical Chemists

Aurongzeb, M., Azim, M. K. (2011) Antimicrobial properties of natural honey: a review of literature. Pakistan Journal of Biochemistry and Molecular Biology, 44 118-124.

Aworh, O. C., Egounlety, M. (1985) Preservation of West African soft cheese by chemical treatment. Journal of Dairy Research, 52 189-195.

Aworh, O. C., Muller, H. (1987) Cheese-making properties of vegetable rennet from Sodom apple (Calotropis procera). Food Chemistry, 26 71-79.

Badmos, A., Abdulsalam, K. (2012) Comparative Evaluation of Cheese samples treated with Honey and Thyme solutions. Journal of Agricultural Research and Development, 11 313-318.

Badmos, A., Ajiboye, D. (2012) The effect of crude leaf extracts of Moringa oleifera on the bacterial, nutritional and sensory properties of West African soft cheese. Wayamba Journal of Animal Science-ISSN, 57 939-946.
Badmos, A., Imam, A., Annongu, A., Yusuff, A., Kayode, R., Salami, K., Ahutu, I., Lawal, A. (2017) Preservative effects of aqueous and ether extracts of Aframomum melegueta on West African soft cheese. Bangladesh Journal of Animal Science, 46 51-56.

Badmos, A., Joseph, K. (2012) Effects of Fermented Maize Supernatant and Sodom Apple Coagulant on the Time, Temperature and of Coagulation of Soft Cheese. Journal of Agricultural Research and Development, 11 328-332.

Balogun, M. A., Kolawole, F. L., Joseph, J., Adebisi, T. T., Ogunleye, O. T. (2016) Effect of fortification of fresh cow milk with coconut milk on the proximate composition and yield of warankashi, a traditional cheese. Croatian Journal of Food Science and Technology, 8 10-14.

Belewu, M., Belewu, K., Nkwunonwo, C. (2005) Effect of biological and chemical preservatives on the shelf life of West African soft cheese. African Journal of Biotechnology, 4 1076-1079.

Belewu, M., El-Imam, A., Adeyemi, K., Oladunjoye, S. (2012) Eucalyptus oil and lemon grass oil: effect on chemical composition and shelf-life of soft cheese. Environment and Natural Resources Research, 2 114-116.

Belewu, M. A., Belewu, K. Y., Adebisi, M. B., Esan, O. T., Fashola, Y. A., Belewu, N. O. (2013) Physicochemical evaluation of garlic oil on the nutritive and shelf-life of cheese. International Journal of Science and Nature, 4 699-701.

Cuffia, F., Candioti, M., Bergamini, C. (2015) Effect of brine concentration on the ripening of an Argentinean sheep's milk cheese. Small Ruminant Research, 132 60-66.

Derar, A., El Zubeir, I. (2014) Compositional Content of White Cheese Manufactured from Mixtures of Camel and Sheep Milk during Storage. Journal of Food and Nutritional Disorders, 3 1-5.

Donnenberg, M. S. (2010) Principles and Practice of Infectious Diseases. 7th. Philadelphia, Pa: Churchill Livingstone Elsevier.

Fawole, O., Abioye, O. (2002) Comparative effectiveness of husk of Parkia biglobosa wild Bent.Mitta and Benomyl in controlling Fusarim wilt disease of Cowpea. Journal of Nigerian Society of Experimental Biology, 2 57-63.

Joseph, J., Akinyosoye, F. (1997) Comparative studies on red sorghum extracts and other chemicals as preservatives for West African soft cheese. International Dairy Journal, 7 193198.

Kalita, S., Kumar, G., Karthik, L., Rao, K. V. B. (2012) A review on medicinal properties of Lantana camara Linn. Research Journal of Pharmacy and Technology, 5 711-715.

Moyo, B., Masika, P., Hugo, A., Muchenje, V. (2011) Nutritional characterization of Moringa (Moringa oleifera Lam.) leaves. African Journal of Biotechnology, 10 12925-12933.

Ogundiwin, J., Oke, O. (1983) Factors affecting the processing of wara-a Nigerian white cheese. Food Chemistry, 11 1-13.

Raheem, B. (2006) Developments and microbiological applications in African foods: Emphasis on Nigerian wara cheese. Ph.D. Thesis. University of Helsinki, Finland,

Twumasi, S., Awudza, J. (2013) Chemical analyses of aqueous extract of Parkia biglobosa fruit husk collected from Northern Ghana. Scientific Research and Essays, 8 589-595. 
Table 1. Ratio of honey and ether extract of P. biglobosa husk in the cheese*

\begin{tabular}{|c|c|c|}
\hline Treatments & Honey (\%) & $\begin{array}{c}\text { P. biglobosa husk } \\
\text { (\%) }\end{array}$ \\
\hline 1 & 0 & 0 \\
\hline 2 & 4 & 0 \\
\hline 3 & 3 & 1 \\
\hline 4 & 2 & 2 \\
\hline 5 & 1 & 3 \\
\hline 6 & 0 & 4 \\
\hline 7 & 4 & 4 \\
\hline
\end{tabular}

*N Ratio is in percentage of $1000 \mathrm{~mL}$ milk used: $3 / 1$ in Treatment 3 means $30 \mathrm{~mL}$ Honey solution $+10 \mathrm{~mL}$ P. biglobosa husk extract were used as cheese fortification.

Table 2. Proximate composition of honey and P. biglobosa husk treated cheese samples (\%)

\begin{tabular}{|l|c|c|c|c|c|}
\hline $\begin{array}{l}\text { Tre- } \\
\text { atments }\end{array}$ & Moisture & Protein & Fat & Ash & *CHO \\
\hline 1 & $59.26^{\mathrm{a}}$ & $13.42^{\mathrm{ab}}$ & $12.44^{\mathrm{e}}$ & $4.64^{\mathrm{a}}$ & $10.24^{\mathrm{c}}$ \\
\hline 2 & $59.69^{\mathrm{a}}$ & $13.13^{\mathrm{b}}$ & $14.28^{\mathrm{c}}$ & $3.79^{\mathrm{a}}$ & $9.11^{\mathrm{d}}$ \\
\hline 3 & $58.52^{\mathrm{b}}$ & $13.21^{\mathrm{b}}$ & $15.84^{\mathrm{b}}$ & $1.86^{\mathrm{c}}$ & $10.57^{\mathrm{c}}$ \\
\hline 4 & $58.54^{\mathrm{b}}$ & $13.06^{\mathrm{b}}$ & $13.20^{\mathrm{d}}$ & $3.17^{\mathrm{b}}$ & $12.03^{\mathrm{b}}$ \\
\hline 5 & $57.07^{\mathrm{c}}$ & $13.99^{\mathrm{a}}$ & $16.56^{\mathrm{a}}$ & $1.73^{\mathrm{c}}$ & $10.65^{\mathrm{c}}$ \\
\hline 6 & $57.04^{\mathrm{c}}$ & $13.93^{\mathrm{a}}$ & $13.92^{\mathrm{cd}}$ & $1.62^{\mathrm{c}}$ & $13.49^{\mathrm{a}}$ \\
\hline 7 & $57.10^{\mathrm{c}}$ & $13.02^{\mathrm{b}}$ & $12.13^{\mathrm{e}}$ & $3.12^{\mathrm{b}}$ & $14.63^{\mathrm{a}}$ \\
\hline \pm SEM & $0.96^{\mathrm{a}}$ & 0.10 & 0.17 & 0.06 & 0.74 \\
\hline
\end{tabular}

Means in a column with different superscripts are significantly different $(p<0.05)$

*CHO: Total Carbohydrate
Table 3. Mean sensory scores of honey and P. biglobosa husk treated cheese samples

\begin{tabular}{|l|c|c|c|c|c|}
\hline $\begin{array}{l}\text { Tre- } \\
\text { atments }\end{array}$ & Colour & Taste & Aroma & Texture & $\begin{array}{c}\text { General } \\
\text { acceptability }\end{array}$ \\
\hline 1 & $5.70^{\mathrm{c}}$ & $2.10^{\mathrm{c}}$ & $3.38^{\mathrm{c}}$ & $5.07^{\mathrm{b}}$ & $3.67^{\mathrm{b}}$ \\
\hline 2 & $5.03^{\mathrm{c}}$ & $6.50^{\mathrm{a}}$ & $5.12^{\mathrm{a}}$ & $5.76^{\mathrm{b}}$ & $6.55^{\mathrm{a}}$ \\
\hline 3 & $6.08^{\mathrm{b}}$ & $6.51^{\mathrm{a}}$ & $5.22^{\mathrm{a}}$ & $5.30^{\mathrm{b}}$ & $6.93^{\mathrm{a}}$ \\
\hline 4 & $6.31^{\mathrm{b}}$ & $6.38^{\mathrm{a}}$ & $5.75^{\mathrm{a}}$ & $5.62^{\mathrm{b}}$ & $7.04^{\mathrm{a}}$ \\
\hline 5 & $6.15^{\mathrm{a}}$ & $6.49^{\mathrm{a}}$ & $5.44^{\mathrm{a}}$ & $5.77^{\mathrm{b}}$ & $6.72^{\mathrm{a}}$ \\
\hline 6 & $7.24^{\mathrm{a}}$ & $6.35^{\mathrm{a}}$ & $5.95^{\mathrm{a}}$ & $6.59^{\mathrm{a}}$ & $6.79^{\mathrm{a}}$ \\
\hline 7 & $5.02^{\mathrm{c}}$ & $4.50^{\mathrm{b}}$ & $4.50^{\mathrm{b}}$ & $5.25^{\mathrm{b}}$ & $4.00^{\mathrm{b}}$ \\
\hline \pm SEM & 0.27 & 0.14 & 0.14 & 0.08 & 0.10 \\
\hline
\end{tabular}

Means in a column with different superscripts are significantly different $(\mathrm{p}<0.05)$

Table 4. Total bacterial count (TBC) of honey and P. biglobosa husk treated cheese samples (Log cfu/g)

\begin{tabular}{|l|l|l|l|}
\hline Treatments & Day 0 & Day 2 & Day 4 \\
\hline 1 & $6.28^{\mathrm{a}}$ & $6.65^{\mathrm{a}}$ & $7.26^{\mathrm{a}}$ \\
\hline 2 & $6.19^{\mathrm{a}}$ & $6.22^{\mathrm{b}}$ & $6.56^{\mathrm{c}}$ \\
\hline 3 & $6.08^{\mathrm{b}}$ & $5.52^{\mathrm{c}}$ & $6.00^{\mathrm{d}}$ \\
\hline 4 & $6.09^{\mathrm{b}}$ & $6.22^{\mathrm{b}}$ & $6.42^{\mathrm{c}}$ \\
\hline 5 & $6.04^{\mathrm{b}}$ & $6.37^{\mathrm{b}}$ & $5.52^{\mathrm{e}}$ \\
\hline 6 & $6.11^{\mathrm{b}}$ & $6.56^{\mathrm{a}}$ & $7.05^{\mathrm{b}}$ \\
\hline 7 & $6.23^{\mathrm{a}}$ & $6.38^{\mathrm{b}}$ & $6.63^{\mathrm{c}}$ \\
\hline
\end{tabular}

Means in a column with different superscripts are significantly different $(\mathrm{p}<0.05)$

Table 5. Bacteria species isolated with Microbact identification Kit.

\begin{tabular}{|l|l|l|l|}
\hline Organism & Day 0 & Day 2 & Day 4 \\
\hline Acitenobacter baumannii & - & + & - \\
\hline $\begin{array}{l}\text { Strenotrophomonas malto- } \\
\text { philia }\end{array}$ & + & - & - \\
\hline Serratia odonrifera & + & - & + \\
\hline Serratia liqueficiens & + & - & + \\
\hline
\end{tabular}

